\title{
Residual stress study in oxide scale obtained on high temperature oxidation of AISI 430 stainless steel
}

\author{
Ning LI*, Ji XIAO, Nathalie PRUD'HOMME, Vincent JI
}

ICMMO/SP2M UMR CNRS 8182, Université Paris-Sud, bat. 410, 91405 Orsay Cédex France

ning.li@u-psud.fr, ji.xiao@u-psud.fr, nathalie.prudhomme@u-psud.fr, vincent.ji@u-psud.fr

Keywords: Solid oxide fuel cell; AISI 430 stainless steel; Oxidation; Residual stress

\begin{abstract}
The objective of this work was to investigate high temperature oxidation behavior of AISI 430 stainless steel, which was proposed to use as interconnector in the planar solid oxide fuel cells (SOFCs). The oxidation of the alloy has been conducted at $700^{\circ} \mathrm{C}, 800^{\circ} \mathrm{C}$ and $900^{\circ} \mathrm{C}$ for $12 \mathrm{~h}$ $96 \mathrm{~h}$ by thermal gravimetric analysis (TGA) system. The oxide surface morphology, cross-section microstructure and the chemical composition of the oxide scales were performed by FEG-SEM and EDX. The X-ray diffraction (XRD) was used to identify the oxide phases formed on the alloy and to determine the residual stress in the scale. It has been found that the oxide scale composed of a inner $\mathrm{Cr}_{2} \mathrm{O}_{3}$ layer and an outer $\mathrm{Mn}_{1.5} \mathrm{Cr}_{1.5} \mathrm{O}_{4}$ layer. The residual stresses in both oxide layers are compressive and the residual stress evolutions in the two layers are different according the oxidation temperature.
\end{abstract}

\section{Introduction}

Solid oxide fuel cells (SOFCs) are electrochemical devices that convert fuel and oxidant gases into electricity. The reduction of the SOFCs operating temperature from $1000^{\circ} \mathrm{C}$ to about $800^{\circ} \mathrm{C}$ in recent years widens the materials choice for stack component such as the interconnects [1-5]. Ferritic stainless steels have many advantages, such as good electrical conductivity, appropriate thermal expansion coefficient and low cost, are among the most promising candidates as the SOFC interconnects.

Many oxidation studies have been done for ferritic steel at high temperature, but all these works were mainly focused on oxidation kinetics. However, in the oxide scale systematically accompanied the development of growth stresses during isothermal oxidation and thermal stress during cooling, which also limit the lifetime of the alloy. Although some works have been done for Ni-Cr alloy found that the oxide growth stresses are negligible [6-8], seldom works have been done for ferritic stainless steels. The aim of the present study is to investigate the residual stresses in the oxide scale after high temperature oxidation of AISI 430 ferritic stainless steel.

\section{Experimental method}

The AISI 430 ferritic stainless steel used in this work was supplied by PX Precimet SA, the chemical composition is listed in Table 1. For the thermal gravimetric analysis (TGA), the samples were cut to a dimension of $10 \mathrm{~mm} \times 10 \mathrm{~mm} \times 1 \mathrm{~mm}$, and a small hole of $0.8 \mathrm{~mm}$ in diameter near an edge to hang them by Platinum cricket in the TGA system. All samples polished by SiC paper followed by silicon paste (up to $2 \mu \mathrm{m}$ ) to make sure the samples have the same surface condition. The TGA (model SETARAM 92-16.18) was employed to study the oxidation kinetics, the experiments have been carried out at $700^{\circ} \mathrm{C}, 800^{\circ} \mathrm{C}$ and $900^{\circ} \mathrm{C}$ for $12 \mathrm{~h}-96 \mathrm{~h}$ in artificial air. Each oxidation condition has been preformed with at least 2 samples, the results were reproducible.

Table 1. Chemical composition of AISI 430 stainless steel (weight \%)

\begin{tabular}{ccccccc}
\hline $\mathrm{Fe}$ & $\mathrm{Cr}$ & $\mathrm{Mn}$ & $\mathrm{Si}$ & $\mathrm{P}$ & $\mathrm{S}$ & $\mathrm{C}$ \\
\hline Bal. & $16-18$ & $<1.00$ & $<1.00$ & $<0.04$ & $<0.03$ & $<0.08$ \\
\hline
\end{tabular}


After oxidation, the surface morphology and composition of the oxide scale and the crosssection microstructure were examined by a FEG-SEM (ZEISS SUPRA 55VP) equipped with an EDX system (Energy-dispersive X-ray spectroscopy). Grazing Incidence X-ray diffraction (GIXRD) technique has been used for oxide phase identification with Panalytical X'Pert under Copper radiation $\left(\lambda_{\mathrm{K} \alpha}=0.154 \mathrm{~nm}\right)$ with a fixed incident angle of $2^{\circ}$, and the analyzed depth is about $3 \mu \mathrm{m}$.

For residual stress analysis in oxide layers, European standard NF EN 15305 (version of April 2009) [9] has been applied with XRD method [10]. The $\{104\}$ peaks for $\mathrm{Cr}_{2} \mathrm{O}_{3},\{311\}$ peaks for $\mathrm{Mn}_{1.5} \mathrm{Cr}_{1.5} \mathrm{O}_{4}$ and $\{110\}$ peaks for substrate were selected to determine the residual stress level because these peaks provide sufficient intensities, and more than 13 peaks with different Psi angles (varying from $-60^{\circ}$ to $+60^{\circ}$ ) have been recorded. Because of high resolution configuration of XRD system, the peak position error determination is less than $0.005 \%$ whatever the $2 \theta$ position.

\section{Results and discussion}

\subsection{Oxidation kinetics}

Fig. 1 shows the mass gain curve as a function of isothermal oxidation duration at $700^{\circ} \mathrm{C}$, $800^{\circ} \mathrm{C}$ and $900^{\circ} \mathrm{C}$, it is clear that all the oxidation rates obeyed a parabolic law [11]:

$$
(\Delta \mathrm{M} / \mathrm{S})^{2}=\mathrm{k}_{\mathrm{p}} \mathrm{t}
$$

where $\Delta \mathrm{M}$ is the weight change, $\mathrm{S}$ is the surface area of the sample, $\mathrm{k}_{\mathrm{p}}$ is the parabolic rate constant and $t$ is the oxidation time. The parabolic rate constants calculated from the kinetic curves are listed in Table 2. According to Wagner theory, a parabolic oxidation rate indicates the formation of a protective scale acting as a diffusion barrier and the oxidation kinetics is controlled by ions diffusion through the oxide scale [12]. Fig. 2 shows a linear relationship between $\log k_{\mathrm{p}}$ and $1 / \mathrm{T}$ at different oxidation temperature, and the activation energy is $279.9 \mathrm{KJ} / \mathrm{mol}$ comparable to that obtained by M. Palcut et al. [13].

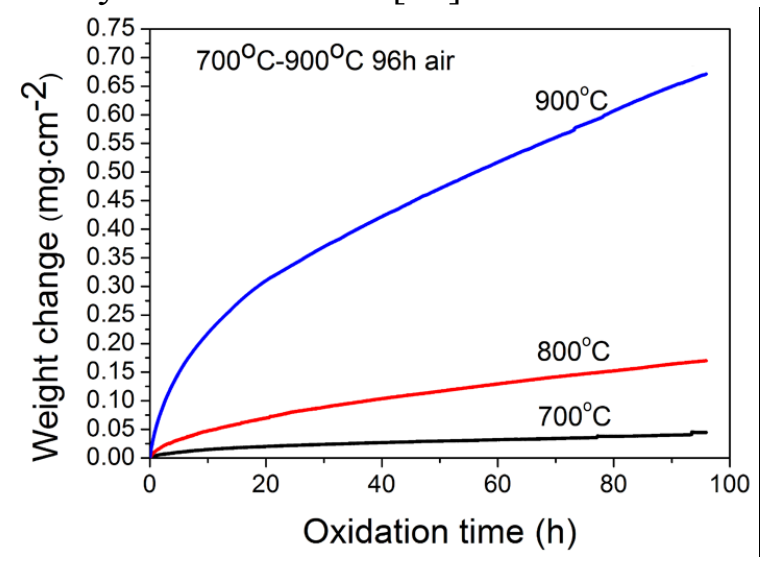

Fig. 1. Weight gain curves of AISI 430 steel during exposure at $700^{\circ} \mathrm{C}, 800^{\circ} \mathrm{C}$ and $900^{\circ} \mathrm{C}$

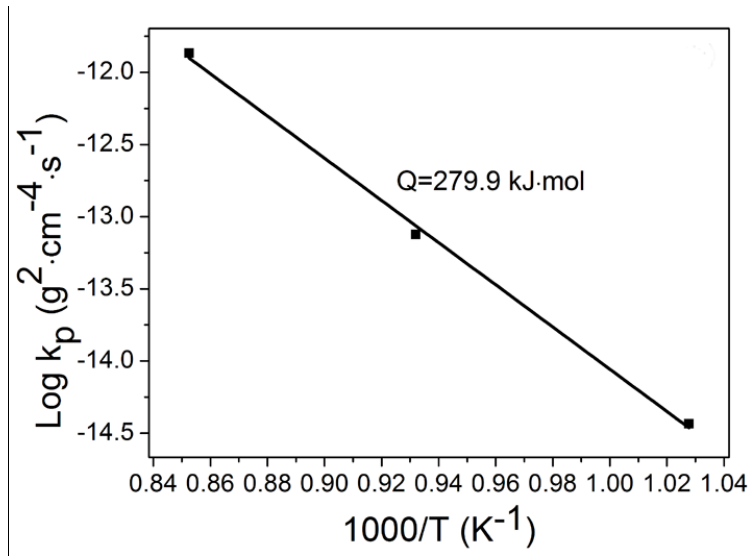

Fig. 2. Log $\mathrm{k}_{\mathrm{p}}$ of AISI 430 as a function of $(1000 / \mathrm{T})$ at $700^{\circ} \mathrm{C}, 800^{\circ} \mathrm{C}$ and $900^{\circ} \mathrm{C}$

Table 2. Parabolic rate constants calculated for the samples after oxidation

\begin{tabular}{ll}
\hline Temperature & $\mathrm{k}_{\mathrm{p}}\left(\mathrm{g}^{2} \mathrm{~cm}^{-4} \mathrm{~s}^{-1}\right)$ \\
\hline $700^{\circ} \mathrm{C}$ & $3.678 \times 10^{-15}$ \\
$800^{\circ} \mathrm{C}$ & $7.527 \times 10^{-14}$ \\
$900^{\circ} \mathrm{C}$ & $1.357 \times 10^{-12}$ \\
\hline
\end{tabular}




\subsection{Microstructure and composition of the scales}

The scale composition and microstructure were studied at room temperature by GIXRD and by FEG-SEM/EDX. Fig.3 shows the GIXRD pattern of AISI 430 stainless steel oxidized for 96h at $700^{\circ} \mathrm{C}, 800^{\circ} \mathrm{C}$ and $900^{\circ} \mathrm{C}$, which indicates the growth of $\mathrm{Cr}_{2} \mathrm{O}_{3}$ (JCPDS 38-1479) and spinel-type $\mathrm{Mn}_{1.5} \mathrm{Cr}_{1.5} \mathrm{O}_{4}$ (JCPDS 33-0892) on the alloy surface. As the oxide scale is very fine, the substrate peaks can also be observed in the XRD pattern. And there are no obvious texture effects, because all XRD intensities correspond to theoretical proportions.

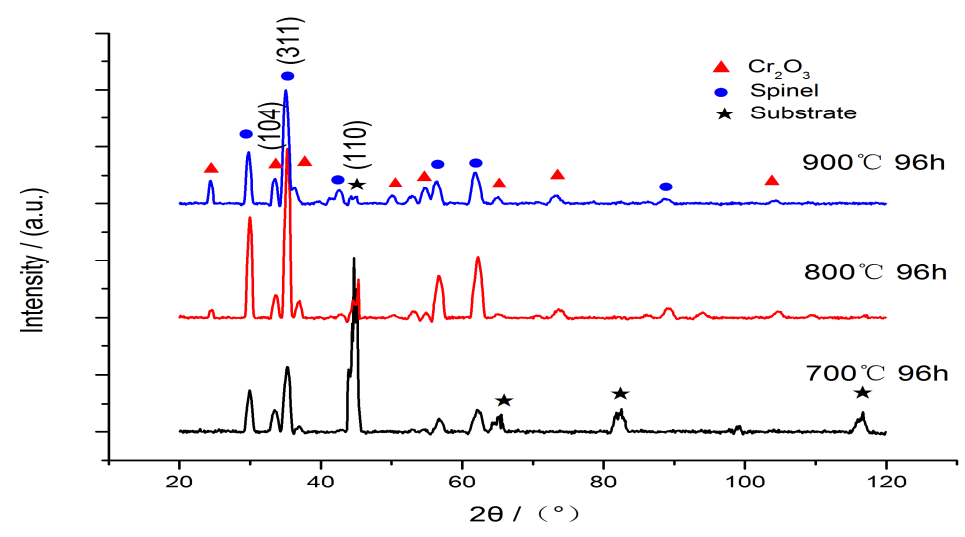

Fig. 3. GIXRD patterns for AISI 430 oxidized at $700^{\circ} \mathrm{C}, 800^{\circ} \mathrm{C}$ and $900^{\circ} \mathrm{C}$ for $96 \mathrm{~h}$ in air

Fig. 4 displays the surface morphology of scale on the substrate oxidized for $48 \mathrm{~h}$ at $900^{\circ} \mathrm{C}$. With the EDX analyses, we observed that the scale is mainly consisted of $\mathrm{Cr}, \mathrm{Mn}$ and oxygen. Observation of the cross section by SEM showed that the oxide scale consisted of two layers, EDX analyses indicates that the outer layer is $\mathrm{Mn}_{1.5} \mathrm{Cr}_{1.5} \mathrm{O}_{4}$ and the inner layer is $\mathrm{Cr}_{2} \mathrm{O}_{3}$ (Fig.5). In the meantime, this can also explain that the relative high intensity of $\mathrm{Mn}_{1.5} \mathrm{Cr}_{1.5} \mathrm{O}_{4}$ peaks occur due to presence of the $\mathrm{Mn}_{1.5} \mathrm{Cr}_{1.5} \mathrm{O}_{4}$ phase in outer part of the scale but not to the higher proportion of $\mathrm{Cr}_{2} \mathrm{O}_{3}$ in the scale. At the beginning of the oxidation, the oxidation was mainly controlled by the outward diffusion of $\mathrm{Cr}^{3+}$, and a protective $\mathrm{Cr}_{2} \mathrm{O}_{3}$ oxide layer formed. After that the oxidation was mainly controlled by the outward diffusion of $\mathrm{Mn}^{3+}$ and a outer spinel layer formed, because $\mathrm{Mn}$ ion diffuses faster than $\mathrm{Cr}^{3+}$ via $\mathrm{Cr}^{3+}$ lattice in $\mathrm{Cr}_{2} \mathrm{O}_{3}$. Since the percentage composition of $\mathrm{Mn}$ in the alloy is small, then the oxidation was controlled by the diffusion of $\mathrm{Cr}^{3+}$ again, and the $\mathrm{Cr}_{2} \mathrm{O}_{3}$ layer thicken, the thickness of the oxide layers after oxidation can be found in the Fig.7 and Fig. 8.

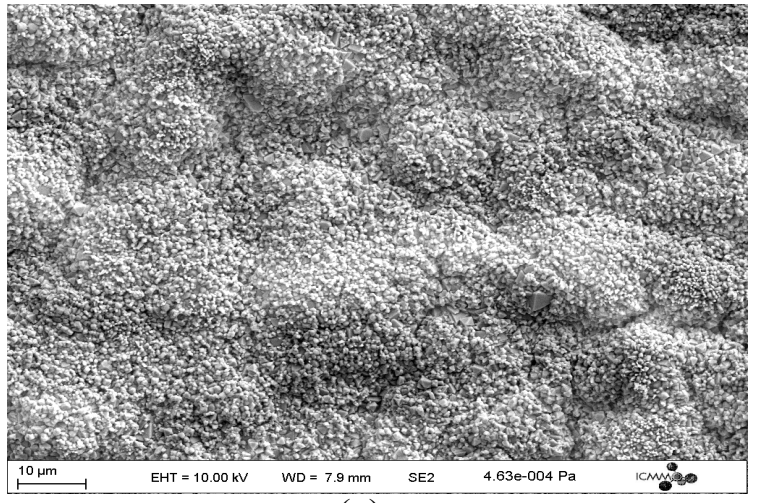

(a)

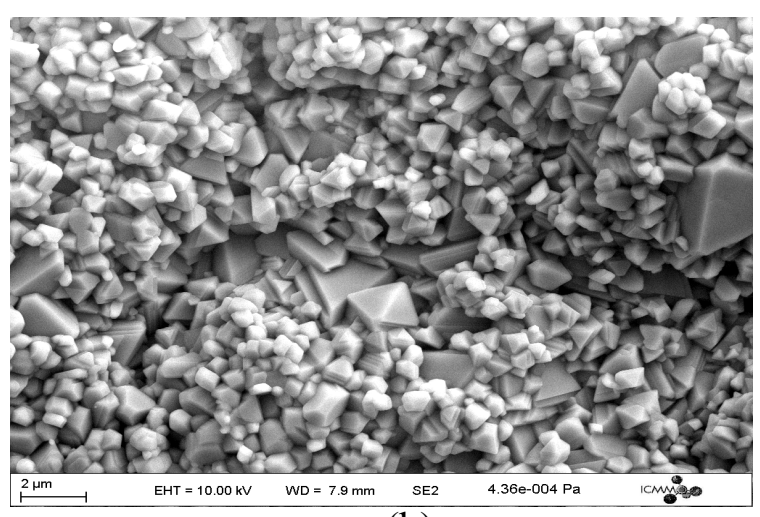

(b)

Fig. 4. SEM surface morphology of AISI 430 oxidized at $900^{\circ} \mathrm{C}$ for $48 \mathrm{~h}$

\subsection{Residual stress analysis}

The in plane residual stresses (RS) in the chromia layer, the spinel layer and the substrate were determined after oxidation at room temperature. The Young's modulus and Poisson's ratio used for the residual stress calculation were $280 \mathrm{MPa}$ and 0.29 for $\mathrm{Cr}_{2} \mathrm{O}_{3}[8,10], 250 \mathrm{MPa}$ and 0.27 
for $\mathrm{Mn}_{1.5} \mathrm{Cr}_{1.5} \mathrm{O}_{4}$ [14], 220MPa and 0.28 for substrate, respectively. The d vs. $\mathrm{f}\left(\sin ^{2} \Psi\right)$ plots are displayed in Fig. 6. For oxide phases, the anisotropic factor has been fixed to be 1 because of the lack of information in bibliography.
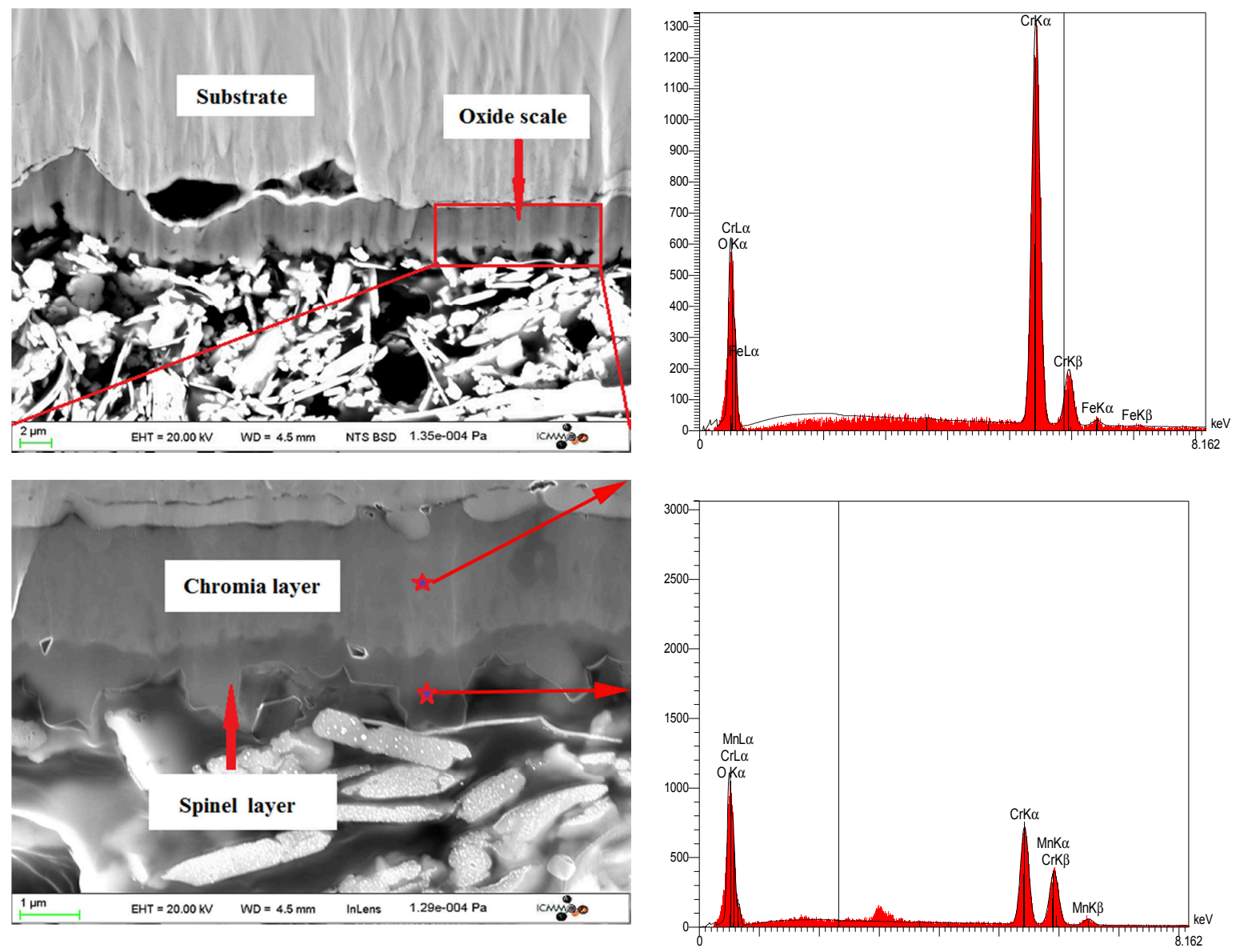

Fig. 5. Cross section after oxidation at $900^{\circ} \mathrm{C}$ for $48 \mathrm{~h}$ and EDX analysis on oxide scale

The results of the RS in oxide scale after oxidation from $12 \mathrm{~h}$ to $96 \mathrm{~h}$ at $900^{\circ} \mathrm{C}$ were shown in Fig. 7, this indicates that the RS are compressive, and as the time goes on, the changing trends of the RS in the spinal layer and the chromia layer are the same at $900^{\circ} \mathrm{C}$. From $12 \mathrm{~h}$ to $24 \mathrm{~h}$ and $48 \mathrm{~h}$ to 96h the RS increased, especially in the spinal scale, which indicates that the growth stress plays an important role in RS for AISI 430, which is in contrary to the previous studies of RS in $\mathrm{Cr}_{2} \mathrm{O}_{3}$ for $\mathrm{Ni}-\mathrm{Cr}$ alloy [6-8]. And from $24 \mathrm{~h}$ to $48 \mathrm{~h}$ the RS decreased, indicates stresses are relaxed as the oxide scale thicken. The stress relief may arise mainly due to the undulation of the scale and the substrate [Fig. 5].
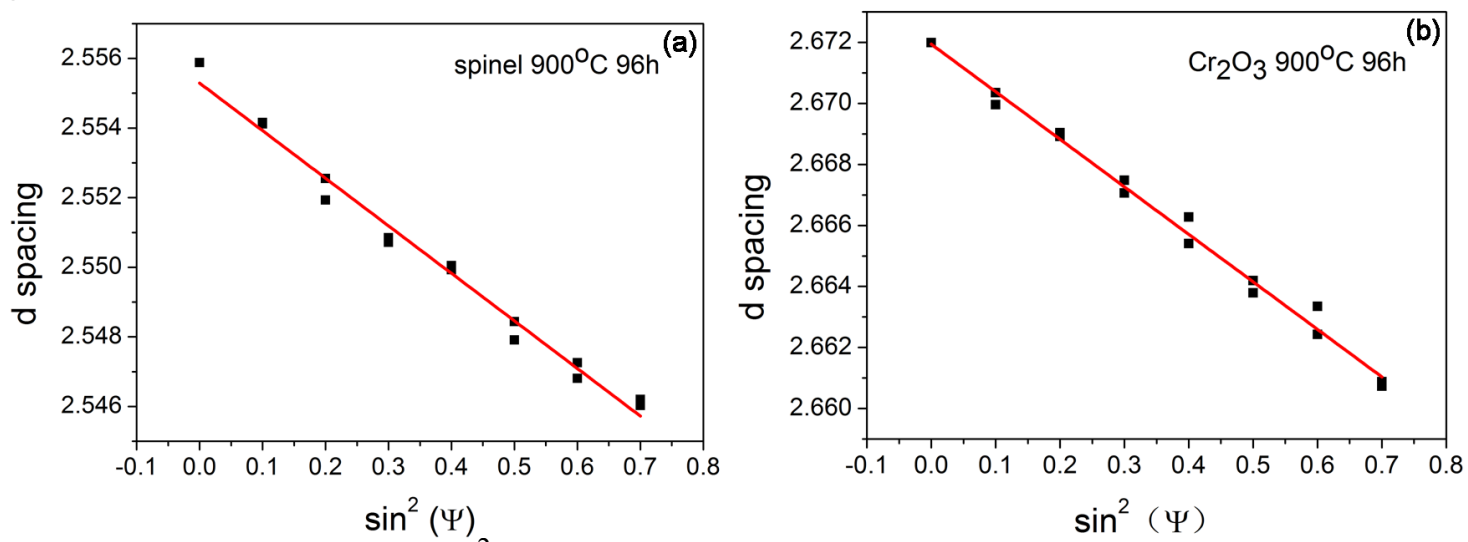

Fig. 6 The $d=f\left(\sin ^{2} \Psi\right)$ plot of oxide layers after oxidation for $96 \mathrm{~h}$ at $900^{\circ} \mathrm{C}$ 
Table 3 lists the RS in substrate after oxidation at $900^{\circ} \mathrm{C}$, in Fig. 3 the intensity of the (110) diffraction peak at $900^{\circ} \mathrm{C}$ is low because it is the pattern of GIXRD. The stresses are small and compressive, there is no much difference between the RS in the substrate with increasing oxidation time. It's in agreement with the result obtained by A.M. Huntz et al. [7] on Nickel. After undulation of the substrate, the stresses are still present may due to good adherence between the oxide scale and the substrate.

Table 3 Residual stress in substrate after oxidation at $900^{\circ} \mathrm{C}$

\begin{tabular}{cc}
\hline Condition & RS in substrate $(\mathrm{MPa})$ \\
\hline $900^{\circ} \mathrm{C} 12 \mathrm{~h}$ & $-80 \pm 10$ \\
$900^{\circ} \mathrm{C} 24 \mathrm{~h}$ & $-90 \pm 10$ \\
$900^{\circ} \mathrm{C} 48 \mathrm{~h}$ & $-95 \pm 15$ \\
$900^{\circ} \mathrm{C} 96 \mathrm{~h}$ & $-75 \pm 20$ \\
\hline
\end{tabular}

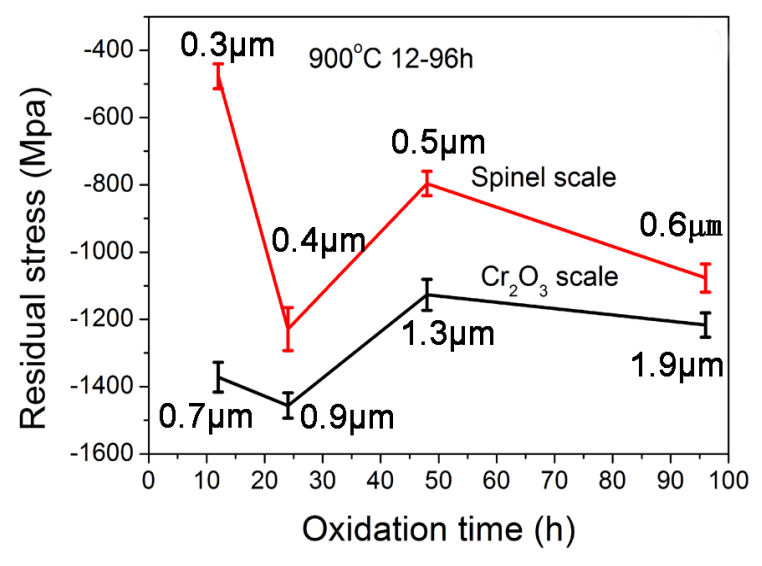

Fig.7 Residual stress in oxide scale after oxidation at $900^{\circ} \mathrm{C}$ for $12 \mathrm{~h}-96 \mathrm{~h}$

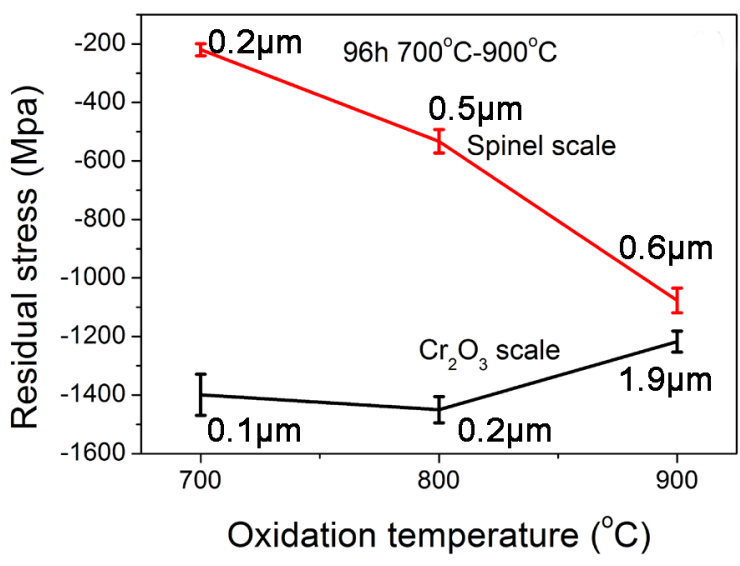

Fig.8 Residual stress in oxide scale after oxidation at $700^{\circ} \mathrm{C}-900^{\circ} \mathrm{C}$ for $96 \mathrm{~h}$

Fig. 8 shows the effect of oxidation temperature on the RS in chromia layer and in spinal layer. It can be seen that the oxidation temperature has different effect on two layers. For the chromia layer, after $96 \mathrm{~h}$ oxidation from $700^{\circ} \mathrm{C}$ to $900^{\circ} \mathrm{C}$, the RS is decreased. But for the spinal layer, the compressive RS increased obviously. So the influences of the temperature on RS in the two layers are definitely different. However, seldom previous theoretical and experimental studies considered this difference, just saw the oxide layers as a whole during calculate and measure the RS. The reason for the RS difference between the two layer are still unknown, more studies need to be done to find the RS relationship between two oxide layers at different oxidation temperature.

\section{Conclusions}

The oxidation of AISI 430 stainless steel have been carried out at $700^{\circ} \mathrm{C}, 800^{\circ} \mathrm{C}$ and $900^{\circ} \mathrm{C}$, the basic conclusions from present work can be made as follows:

(1) The oxide scale is consisted of a inner $\mathrm{Cr}_{2} \mathrm{O}_{3}$ layer and an outer $\mathrm{Mn}_{1.5} \mathrm{Cr}_{1.5} \mathrm{O}_{4}$ layer, and the activation energy is $279.9 \mathrm{KJ} / \mathrm{mol}$;

(2) The residual stresses in both oxide layers are compressive. The growth stress plays an important role in residual stress in oxide scale for AISI 430;

(3) The influences of the temperature on residual stress in the two layers are different, which was unnoticed before. 


\section{References}

[1] S.J. Geng, J.H. Zhu, Promising alloys for intermediate-temperature solid oxide fuel cell interconnect application, J. Power Sources 160 (2006) 1009-1016.

[2] B. Hua, J. Pu, F.S. Lu, J.F. Zhang, B. Chi, L. Jian, Development of a Fe-Cr alloy for interconnect application in intermediate temperature solid oxide fuel cells, J. Power Sources 195 (2010) 2782-2788 .

[3] V. Miguel-Pérez, A. Martínez-Amesti, M.L. Nó, A. Larrañaga, M.I. Arriortua, Oxide scale formation on different metallic interconnects for solid fuel cells, Corros. Sci. 60 (2012) 38-49.

[4] P.P. Edwars, V.L. Kuznetsov, W.I.F. David, N.P. Brandon, Hydrogen and fuel cells: Towards a sustainable energy future, Energy Policy 36 (2008) 4356-4362.

[5] J. Froitzheim, G.H. Meier, L. Niewolak, P.J. Ennis, H. Hattendorf, L. Singheiser, W.J. Quadakkers, Development of high strength ferritic steel for interconnect application in SOFCs, J. Power Sources 178 (2009) 163-173.

[6] S.Daghigh, J.L. Lebrun, A.M. Huntz, Stresses in $\mathrm{Cr}_{2} \mathrm{O}_{3}$ scales developed on Ni-30Cr, Trans Tech Publication, Switzerland, 1997.

[7] A.M.Huntz, C. Liu, M. Kornmeier, J.L. Lebrun, The determination of stresses during oxidation of Ni: In situ measurements by XRD at high temperature, Corros. Sci. 35 (1993) 989-997.

[8] A.M. Huntz, Stresses in $\mathrm{NiO}, \mathrm{Cr}_{2} \mathrm{O}_{3}$ and $\mathrm{Al}_{2} \mathrm{O}_{3}$ oxide scales, Mat. Sci. Eng. A, 201 (1995) 211228.

[9] European Standard no NF15305,Test Method for Residual Stress Analysis by X-ray Diffraction, April(2009).

[10] J. Xiao, N. Prud'homme, N. Li, V. Ji, Influence of humidity on high temperature oxidation of Inconel 600 alloy: Oxide layers and residual stress study, Applied Surface Sci. 284 (2013) 446-452.

[11] A.S. Khanna, High temperature oxidation and corrosion, ASM International, Ohio, USA, 2002.pp. 109-134.

[12] P. Kofstad, High temperature corrosion, Elsevier, Essex, England, 1988.

[13] M. Palcut, L. Mikkelsen, K. Neufeld, M. Chen, R. Knibbe, P.V. Hendriksen, Corrosion stability of ferritic stainless steels for solid oxide electrolyser cell interconnects, Corros. Sci. 52 (2010) 3309-3320.

[14] W.N. Liu, X. Sun, E. Stephens, M.A. Khaleel, Life prediction of coated and uncoated metallic interconnect for solid oxide fuel cell applications, J. Power Sources 189 (2009) 1044-1050. 